\title{
Combination of Hereditary Elliptocytosis and Heterozygous Beta-thalassaemia: A Family Study ${ }^{\star}$
}

\author{
MUZAFFER AKSOY and ŞAKIR ERDEM
}

From Second Internal Clinic of Istanbul Medical School, Istanbul, Turkey

Hereditary elliptocytosis has been described in sporadic association with $\beta$-thalassaemia (Brumpt, Delabarre, and De Traverse, 1960; De Vries, De Jong, and Frenkel, 1959; Aksoy, 1963; Perillie and Chernoff, 1965; Angelopoulos and Caralis, 1965). With the exception of two cases reported by Perillie and Chernoff (1965) and Angelopoulos and Caralis (1965), the combination of hereditary elliptocytosis and heterozygous $\beta$-thalassaemia has not been described in association with mutual enhancement of any of the involved genes. On the other hand, according to Perrillie and Chernoff (1965) and Angelopoulos and Caralis (1965), there is suggestive evidence that the clinical effects of both genes are summated or the expressivity of the involved genes enhanced when they are both present in the same individual.

Recently we have investigated a Turkish family with hereditary elliptocytosis in association with $\beta$-thalassaemia. Of 9 sibs investigated, 3 had the combination of these 2 genes. Interestingly, in these 3 patients with the combination of hereditary elliptocytosis and heterozygous $\beta$-thalassaemia there were some clinical manifestations and haematological findings which suggested the possibility of a mutual enhancement of some of the genes involved.

\section{Material and Methods}

The haematological methods were standard. Haemoglobin analyses were performed by starch gel electrophoresis, using borate buffer at $p \mathrm{H} 8.6$ according to the method of Smithies (1955) and slightly modified by Aksoy and Erdem (1965). Hb F was determined by the method of Singer, Chernoff, and Singer (1951); and quantitative estimations of $\mathrm{Hb} \mathrm{A}_{2}$ by the method of DEAE-cellulose chromatography following the descriptions of Huisman and Dozy (1961). The relative concentrations of haemoglobin solutions were finally

Received January 22, 1968.

* This study was supported by a grant from the Scientific and Technical Research Council of Turkey. estimated in a Unicam spectrophotometer at $415 \mathrm{~m} \mu$. Measurement of erythrocyte glucose-6-phosphatedehydrogenase activity was determined by the method of Gadsden and Cannon (1964). Faecal urobilinogen was determined by the method of Young, Davis, and Hogestyn (1949) using a comparator block. $\dagger$ In this method normal values for faecal urobilinogen are 50 to 300 Ehrlich Units per $100 \mathrm{~g}$. faeces.

\section{Family Report}

The family was of Turkish origin and living in a village of Dörtyol near Iskenderun. Haematological data for each family member examined are summarized in the Table. The family pedigree is shown in Fig. 1.

The propositus (II.3), a 19-year-old Dental Schoof student, came to our laboratory for haemoglobin analysis? He had been anaemic and icteric from early childhood, and suffered from easy fatiguability, particularly after a sleepless night. Physical examination revealed a welldeveloped, well-nourished boy with subicteric sclerae and pallor. The spleen was enlarged two fingerbreadths below the costal margin. There were no other abnormal findings. The patient's laboratory data are summarized in the Table. A decreased osmotic fragility curve was obtained by quantitative erythrocyte osmotic fragility before and after 24 hours' incubation at $37^{\circ} \mathrm{C}$. Total bilirubin was $2 \cdot 1 \mathrm{mg} . / 100 \mathrm{ml}$., all of which was indirect reacting. Serum iron was $81 \gamma / 100 \mathrm{ml}$; reticulocytes $4.5 \%$; G6PD activity was 157 units $/ 100 \mathrm{ml}$. erythrocytes (normal level for men 135-189 units/100 ml. erythrocytes). A bone survey and a cholecystography revealed no abnormalities.

Blood samples and blood smears from the parents and 8 sibs were sent directly from their village. Haematological data for each family member studied are also recorded in the Table.

\section{Discussion}

The existence of a $\beta$-thalassaemia gene in the propositus can be seen clearly from the case report, the Table, and Fig. 1. The criteria are as follows: 


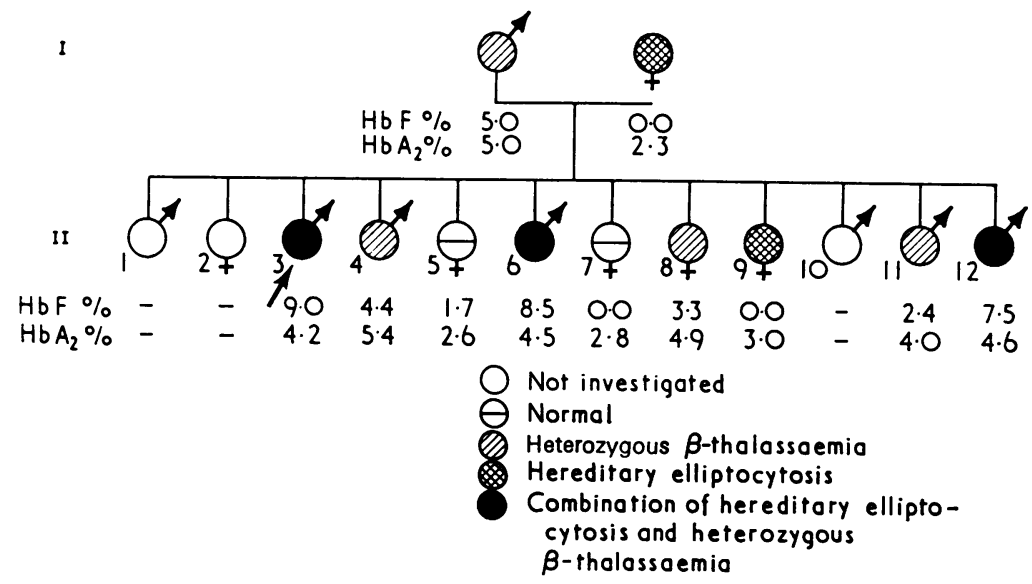

FIg. 1. Pedigree of a family with the combination of hereditary elliptocytosis and heterozygous $\beta$ thalassaemia.

TABLE

HAEMATOLOGICAL AND BIOCHEMICAL FINDINGS OF FAMILY WITH COMBINATION OF HEREDITARY ELLIPTOCYTOSIS AND HETEROZYGOUS $\beta$-THALASSAEMIA

\begin{tabular}{|c|c|c|c|c|c|c|c|c|c|c|c|c|c|}
\hline $\begin{array}{c}\text { Pedigree } \\
\text { and } \\
\text { Designation }\end{array}$ & $\underset{(\mathrm{g} . / 100 \mathrm{ml} .)}{\mathrm{Hb}}$ & $\underset{10^{6}}{\operatorname{RBC} /}$ & $\begin{array}{c}\text { Haema- } \\
\text { tocrit } \\
(\%)\end{array}$ & $\underset{\mu^{3}}{\mathrm{MCV}}$ & $\underset{\gamma \gamma}{\mathrm{MCH}}$ & $\begin{array}{l}\text { Target } \\
\text { Cells }\end{array}$ & $\begin{array}{l}\text { Ovalo- } \\
\text { cytosis }\end{array}$ & $\begin{array}{l}\text { Ellipto- } \\
\text { cytosis }\end{array}$ & $\begin{array}{l}\text { Micro- } \\
\text { cytosis }\end{array}$ & $\underset{\text { chromia }}{\text { Hypo- }}$ & $\begin{array}{l}\text { Poikilo- } \\
\text { cytosis }\end{array}$ & $\underset{\%}{\mathbf{H b}} \mathbf{F}$ & $\underset{\%}{\mathbf{H b}} \mathbf{A}_{\mathbf{2}}$ \\
\hline $\begin{array}{l}\text { I. } 1 \\
\text { I. } 2 \\
\text { II. } 3 \\
\text { II. } 4 \\
\text { II. } 5 \\
\text { II. } 6 \\
\text { II. } 7 \\
\text { II. } 8 \\
\text { II. } 9 \\
\text { III. } 11 \\
\text { II. } 12\end{array}$ & $\begin{array}{r}12.3 \\
12.0 \\
9.1 \\
11.0 \\
13.0 \\
9.4 \\
13.5 \\
12.0 \\
12.5 \\
11.0 \\
9.4\end{array}$ & $\begin{array}{l}5 \cdot 30 \\
3.90 \\
4.90 \\
4.95 \\
4 \cdot 80 \\
4 \cdot 60 \\
4 \cdot 80 \\
4 \cdot 80 \\
4 \cdot 85 \\
4 \cdot 80 \\
4 \cdot 60\end{array}$ & $\begin{array}{l}44 \\
37 \\
37 \\
38 \\
42 \\
38 \\
43 \\
39 \\
44 \\
39 \\
37\end{array}$ & $\begin{array}{l}82 \\
94 \\
75 \\
81 \\
87 \\
82 \\
89 \\
80 \\
91 \\
80 \\
80\end{array}$ & $\begin{array}{l}23 \\
30 \\
18 \\
22 \\
27 \\
24 \\
28 \\
25 \\
26 \\
21 \\
20\end{array}$ & $\begin{array}{c}++ \\
- \\
+ \\
++ \\
+ \\
+ \\
+ \\
+ \\
++ \\
+\end{array}$ & $\begin{array}{c}+ \\
++ \\
+ \\
++ \\
- \\
++ \\
+ \\
+ \\
+ \\
+ \\
++\end{array}$ & $\begin{array}{c}- \\
++ \\
+++t \\
- \\
\bar{t}+ \\
- \\
- \\
+ \\
++\end{array}$ & $\begin{array}{c}+ \\
- \\
++ \\
+ \\
\overline{+} \\
+ \\
+ \\
- \\
++ \\
++\end{array}$ & $\begin{array}{c}++ \\
- \\
++ \\
++ \\
- \\
++ \\
++ \\
- \\
++ \\
++\end{array}$ & $\begin{array}{c}- \\
- \\
++ \\
\bar{f} \\
\overline{+} \\
\overline{-} \\
\overline{-} \\
\overline{+}\end{array}$ & $\begin{array}{l}5 \cdot 0 \\
0 \\
9 \cdot 0 \\
4 \cdot 4 \\
1 \cdot 7 \\
8 \cdot 5 \\
0 \\
3 \cdot 3 \\
0 \\
2 \cdot 4 \\
7 \cdot 5\end{array}$ & $\begin{array}{l}5 \cdot 0 \\
2 \cdot 3 \\
4 \cdot 2 \\
5 \cdot 4 \\
2 \cdot 6 \\
4 \cdot 5 \\
2 \cdot 8 \\
4 \cdot 9 \\
3 \cdot 0 \\
4 \cdot 6 \\
4 \cdot 6\end{array}$ \\
\hline
\end{tabular}

raised levels of $\mathrm{Hb} \mathrm{A}_{2}$ and $\mathrm{Hb} \mathrm{F}$, hypochromia, microcytosis, poikilocytosis, targeting, decreased red cell fragility, and normal serum iron level. On the other hand, the marked elliptocytosis in the blood smear (Fig. 2) was an indication for the possible presence of the elliptocytic gene in the propositus.* The final proof of this possibility was provided by the results of the genetic study. The father had the stigmata of heterozygous $\beta$-thalassaemia, i.e. decreased mean corpuscular volume and mean corpuscular $\mathrm{Hb}$, microcytosis, hypochromia, targeting (Fig. 2), and particularly increased levels of $\mathrm{Hb} \mathrm{A}_{2}$ and $\mathrm{F}$. On the other hand, the mother had the morphological criteria characteristic of hereditary elliptocytosis (Fig. 2). Of 12 offspring, 9 were investigated (Fig. 1). Two of them (II.5 and II.7) were normal. One (II.9) had, like her mother, an asymptomatic form of hereditary elliptocytosis. Three sibs (II.4, II.8, and II.11)

\footnotetext{
* We noticed that some of the elliptocytes or ovalocytes also showed target cell form. We might call these, ellipto-target cells see Fig. 2).
}

had, like their father, the above-mentioned haematological findings of heterozygous $\beta$-thalassaemia. In addition to the propositus (II.3), 2 other sibs (II.6 and II.12) had the combination of hereditary elliptocytosis and heterozygous $\beta$-thalassaemia. The criteria are as follows: decreased mean corpuscular volume and mean corpuscular $\mathrm{Hb}$, increased levels of foetal $\mathrm{Hb}$ and $\mathrm{Hb} \mathrm{A}_{2}$, hypochromia, microcytosis, poikilocytosis, targeting, and marked elliptocytosis.

If we compare the clinical manifestations and haematological findings of the propositus, his 2 similar sibs (II.6 and II.12), and those of the other members of his family (Table), there is strong reason for supposing that there was a mutual enhancement of the expressivity of the involved genes in this family, with the combination of hereditary elliptocytosis and heterozygous $\beta$-thalassaemia. The criteria supporting this assumption are as follows (1) Level of haemoglobin: though the level in the family members carrying one gene responsible either for hereditary elliptocytosis or $\beta$-thalassaemia (I.1, I.2, II.4, II.8, II.9, and II.11) was not less 

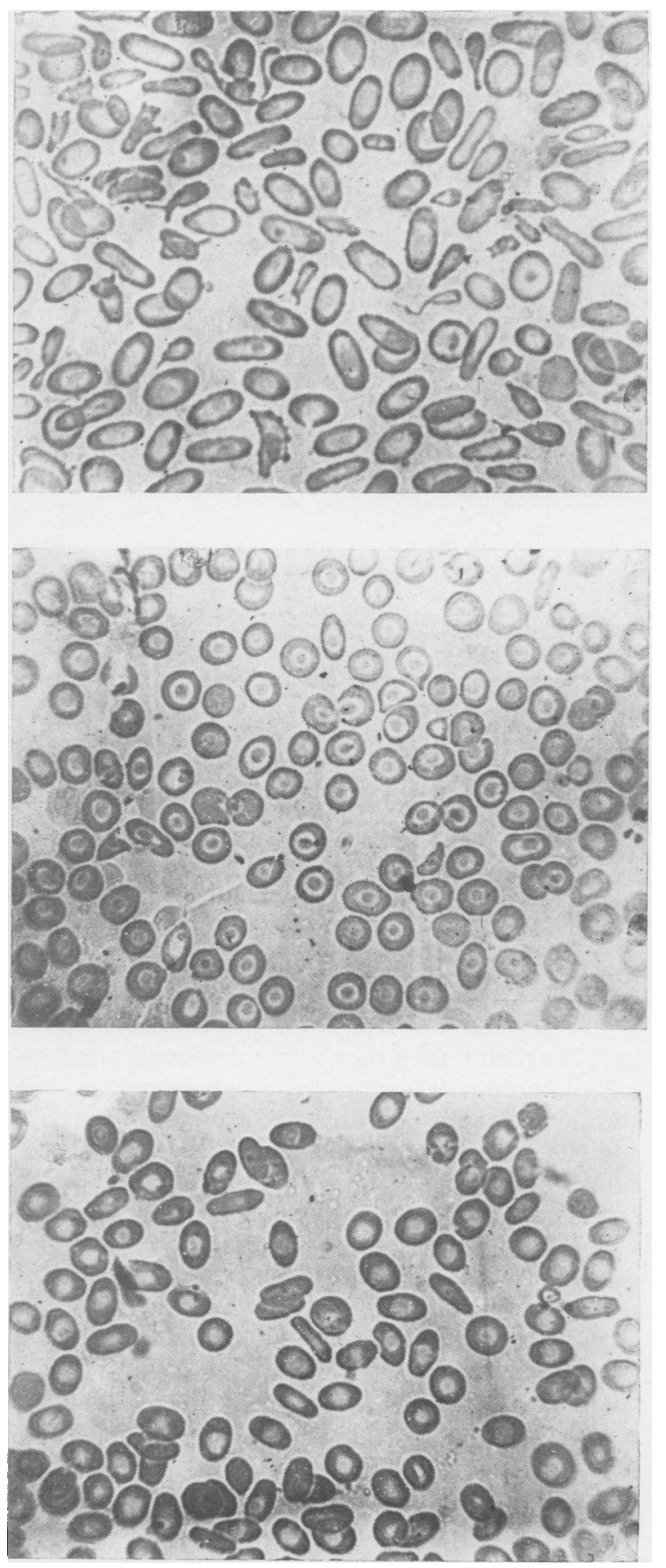

FIG. 2. (a) Photomicrograph of the blood film of the propositus (II.3), demonstrating marked elliptocytosis, ovalocytosis, microcytosis, hypochromia, targeting, and poikilocytosis. There are also some 'ellipto-target cells'. (b) Photomicrograph of the blood film of the father (I.1) showing marked targeting and hypochromia. (c) Photomicrograph of the blood film of the mother (I.2) showing marked ovalocytosis and elliptocytosis. than $11 \mathrm{~g} . / 100 \mathrm{ml}$, the level in 3 patients with the combination of hereditary elliptocytosis and heterozygous $\beta$-thalassaemia (II.3, II.6, and II.12) was less than $10,9 \cdot 1$, and $9.4 \mathrm{~g} . / 100 \mathrm{ml}$., respectively. (2) Level of foetal haemoglobin: though the level found in 4 family members with heterozygous $\beta$ thalassaemia (I.1, II.4, II.8, and II.11) was less than $5 \%$ (mean foetal concentration $3.8 \%$ ), the content of foetal $\mathrm{Hb}$ was more than $5 \%$ (mean concentration $8.3 \%$, little more than twice the former value) in 3 sibs with the combination of hereditary elliptocytosis and heterozygous $\beta$-thalassaemia (II.3, II.6, and II.12), 9, 8.5, and $7.5 \%$, respectively. This is particularly significant in view of the reported intrafamilial similarity of the levels of $\mathrm{Hb} \mathrm{F}$ in thalassaemia.

Bearing these facts in mind, we think that the uncompensated haemolytic anaemia present in the propositus is the result of the mutual enhancement of any of the involved genes, namely the genes responsible for hereditary elliptocytosis and $\beta$-thalassaemia. On the other hand, most of the previous reports concerning the combination of hereditary elliptocytosis and heterozygous $\beta$-thalassaemia did not appear to show this mutual enhancement (Brumpt et al., 1960; De Vries et al., 1959; Aksoy, 1963). On the contrary, the uncompensated haemolytio anaemia found in the patients with the comen bination of hereditary elliptocytosis and heterozy gous $\beta$-thalassaemia represents either a summation of the clinical effects of the involved genes (Perillie and Chernoff, 1965), or the expressivity of the gene for hereditary elliptocytosis is affected by some of the genes responsible for $\beta$-thalassaemia (Angelopoulos and Caralis, 1965).

If one compares the previous descriptions of the combination of hereditary elliptocytosis and heterozygous $\beta$-thalassaemia by Brumpt et al. (1960), De Vries et al. (1959), and Aksoy (1963), with those of Perillie and Chernoff (1965) and Angelopoulos and Caralis (1965), and the present family, haemoglobinopathy can be classified into two types. (1) The combination of hereditary elliptocytosis and heterozygous $\beta$-thalassaemia without mutual enhancement of the involved genes. (2) The combination of hereditary elliptocytosis and heterozygous $\beta$-thalassaemia with either a summation of the clinical effects of the genes or mutual enhancement of any of the involved genes.

This may be explained by the existence of more than one kind of gene for $\beta$-thalassaemia and hereditary elliptocytosis.

\section{Summary}

Some of the members of the family reported in 
this paper have either a $\beta$-thalassaemia or a hereditary elliptocytosis gene alone, while others show a combination of these two genes. In 3 sibs with the combination of these two genes, haematological findings suggest a mutual enhancement of the effects of these two particular genes present in this family. Considering also other reported cases, the authors think that the combination of hereditary elliptocytosis and $\beta$-thalassaemia should be divided into two types, according to whether these two genes show a mutual enhancement of their effects or not.

\section{REFERENCES}

Aksoy, M. (1963). The combination of hereditary elliptocytosis with heterozygous beta-thalassaemia. Study of a Turkish family. Acta haemat. (Basel), 30, 215.

and Erdem, S. (1965). A simple method for the quantitation of haemoglobin $\mathbf{A}_{2}$ by starch gel electrophoresis. Clin. chim. Acta, 12, 696.

Angelopoulos, B., and Caralis, D. (1965). Hereditary elliptocytosis associated with heterozygous beta-thalassaemia. A study in a Greek family. Ann. paediat. (Basel), 204, 336.
Brumpt, L. C., Delabarre, F., and De Traverse, P. M. (1960). Double hétérozygotie entre thalassémie et elliptocytose. In Proc. IIVth Congr. int. Soc. Hemat., Vol. 2, Pt. 1, p. 451. Pensiero Scientifico, Rome.

De Vries, S. I., De Jong, J., and Frenkel, M. (1959). Anémie elliptocytaire hémolytique. Schweiz. med. Wschr., 89, 1078.

Gadsden, R. H., and Cannon, A. (1964). Measurement of glucose-6 phosphate dehydrogenase activity. In Hemoglobin. Its Precursors and Metabolites, 5th ed., p. 332. Ed. by F. W. Sunderman and F. W. Sunderman, Jr. J. B. Lippincott, Philadelphia.

Huisman, T. H. J., and Dozy, A. M. (1961). Quantitative determination of minor haemoglobin component $\mathrm{Hb}-\mathrm{A}_{2}$ by DEAEchromatography. Anal. Biochem., 2, 400.

Perillie, P. E., and Chernoff, A. I. (1965). Heterozygous betathalassemia in association with hereditary elliptocytosis. A family study. Blood, 25, 494.

Singer, K., Chernoff, A. I., and Singer, L. (1951). Studies on abnormal hemoglobins. I. Their demonstration in sickle cell anemia and other hematologic disorders by means of alkali denaturation. ibid., 6, 413.

Smithies, O. (1955). Zone electrophoresis in starch gells: group variations in the serum proteins of normal human adults. Biochem. F., 61, 629.

Young, L. E., Davis, R. W., and Hogestyn, J. (1949). Simplified equipment for determination of urobilinogen in urine and stool. f. Lab. clin. Med., 34, 287. 